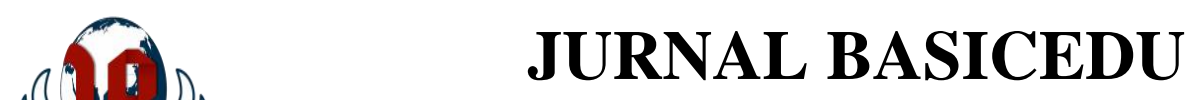

Volume 5 Nomor 4 Tahun 2021 Halaman 2263 - 2269

Research \& Learning in Elementary Education

https://jbasic.org/index.php/basicedu

\title{
Peran Kepala Sekolah dan Guru dalam Menumbuhkan Perilaku Hidup Sehat pada Siswa Sekolah Dasar
}

\author{
Nurul Anisa ${ }^{1 凶}$, Zaka Hadikusuma Ramadhan ${ }^{2}$ \\ Pendidikan Dasar, Universitas Islam Riau, Indonesia ${ }^{1,2}$ \\ E-mail: nurulanisanisa@gmail.com ${ }^{1}$, zakahadi@edu.uir.ac.id² ${ }^{2}$
}

\begin{abstract}
Abstrak
Tujuan dari riset ini mengetahui untuk mengetahui dan mendeskripsikan peran kepala sekolah dan guru dalam menumbuhkan perilaku hidup sehat pada siswa Sekolah Dasar Negeri 29 Pekanbaru. Metode yang digunakan dalam penelitian ini adalah deskriptif kualitatif dengan menggunakan teknik pengumpulan data melalui wawancara, observasi dan dokumentasi. Kemudian teknik analisis data yang digunakan yaitu reduksi data, penyajian data dan kesimpulan. Hasil pada penelitian ini adalah perilaku sehari-hari anak usia sekolah dasar yang menunjukkan kepedulian terhadap kesehatan diri dan lingkungan, dalam perilaku berikut: sarapan sebelum ke sekolah, makan teratur, jajan di kantin/warung yang bersih, makan makanan yang sehat, cuci tangan dengan sabun dan air yang bersih sebelum makan, menggosok gigi, membersihkan kuku dan rambut, menjaga kebersihan wc sekolah, menggunakan pakaian yang bersih, menggunakan sepatu dan kaus kaki yang bersih, membuang sampah pada tempatnya, membersihkan ruangan kelas dan lingkungan sekolah, membiasakan hidup bersih di rumah, serta mengikuti kegiatan olahraga dan aktivitas fisik secara teratur. Penelitian ini dimaksudkan agar peran kepala sekolah dan guru dapat memotivasi siswa untuk menjaga kondisi lingkungan sekolah yang sehat, agar secara mandiri terhindar dari penyakit.
\end{abstract}

Kata Kunci: Peran Kepala Sekolah, Guru, Perilaku Hidup Sehat, Siswa Sekolah Dasar.

\begin{abstract}
The purpose of this research is to find out and describe the role of school principals and teachers in fostering healthy living behaviors in students at the 29 Pekanbaru State Elementary School. The method used in this research is descriptive qualitative by using data collection techniques through interviews, observation and documentation. Then the data analysis techniques used are data reduction, data presentation and conclusions. The results of this study are the daily behavior of elementary school-aged children who show concern for their own health and the environment, in the following behaviors: breakfast before going to school, eating regularly, snacking in a clean canteen/stall, eating healthy food, washing hands thoroughly. clean soap and water before eating, brushing teeth, cleaning nails and hair, maintaining cleanliness of school toilets, using clean clothes, using clean shoes and socks, disposing of garbage in its place, cleaning classrooms and school environment, getting used to clean living in home, as well as participating in sports and physical activities on a regular basis. This research is intended so that the role of principals and teachers can motivate students to maintain a healthy school environment, in order to independently avoid disease.
\end{abstract}

Keywords: Principal's Role, Teachers, Healthy Life Behavior, Elementary School Students.

Copyright (c) 2021 Nurul Anisa, Zaka Hadikusuma Ramadhan

Corresponding author :

Email : nurulanisanisa@gmail.com

DOI : https://doi.org/10.31004/basicedu.v5i4.1196

ISSN 2580-3735 (Media Cetak)

ISSN 2580-1147 (Media Online)

Jurnal Basicedu Vol 5 No 4 Tahun 2021

p-ISSN 2580-3735 e-ISSN 2580-1147 
2264 Peran Kepala Sekolah dan Guru dalam Menumbuhkan Perilaku Hidup Sehat pada Siswa Sekolah Dasar - Nurul Anisa, Zaka Hadikusuma Ramadhan

DOI: https://doi.org/10.31004/basicedu.v5i4.1196

\section{PENDAHULUAN}

Satuan pendidikan yang berfungsi meningkatkan ilmu pengetahuan, sikap, dan keterampilan generasi bangsa sebagai bekal taraf hidup menjadi yang lebih baik adalah pendidikan formal atau sekolah. Sekolah juga merupakan salah satu lembaga yang berperan dalam pembentukan perilaku siswa. Pembentukan perilaku siswa selain dibentuk di sekolah, yang paling utama menentukan adalah lingkungan keluarga, sebelum nantinya siswa akan berinteraksi dengan masyarakat (Indah Prasetyawati Tri Purnama Sari., 2013). Menurut (Rochmah, 2018); (Irwandi, S., Ufatin, N., 2016) menyatakan bahwa tujuan sekolah yaitu mempersiapkan anak didik dalam meningkatkan pengetahuan, sikap, dan keterampilan untuk mencapai taraf dan kualitas hidupnya di lingkungan pembentukan kepribadian anak sangat penting dilakukan oleh semua jenjang sekolah, terutama pada sekolah dasar yang digunakan sebagai pondasi awal dalam mewujudkan pribadi anak untuk masa yang akan datang. Anak yang memiliki kepribadian baik, maka akan berdampak pada prestasi belajar anak yang baik pula (Minsih, M., \& D, 2018).

Menurut (Cvencek, D, 2017) menyatakan bahwa adanya keterkaitan antara kerpibadian dan harga diri siswa di sekolah dasar terhadap pencapaian prestasi akademik anak di masa depan. Salah satu bentuk penanaman kepribadian anak diberikan melalui pendidikan perilaku hidup yang sehat, baik dalam bentuk sosial, fisik, dan psikis. Penanaman pribadi tersebut dapat dimulai sejak dini di bangku sekolah melalui berbagai program pembelajaran (Yufiarti, Y., Edwita, 2019) pernyataan yang sama dari (Kandou, G. D., \& Caroline, 2019) menyarankan bahwa agar sekolah menyediakan lebih banyak fasilitas yang dapat mendukung siswa untuk menerapkan perilaku hidup bersih dan sehat seperti adanya program maupun kebijakan sekolah sehat. Undang-undang Nomor 36 Tahun 2009 pasal 79 tentang kesehatan telah menegaskan bahwa kebijakan kesehatan sekolah diadakan untuk meningkatkan perilaku hidup sehat pada peserta didik dengan tujuan mendorong semangat siswa untuk mengembangkan diri serta mampu mencapai generasi bangsa yang berkualitas. Cara membentuk perilaku hidup sehat siswa adalah dengan condisioning atau kebiasaan (Sulastri, Purna, \& Suyasa, 2014: 103). Menanamkan perilaku hidup sehat pada peserta didik perlu adanya suatu pembiasaan-pembiasaan atau budaya sekolah.

Salah satu bentuk perilaku hidup sehat tercermin pada sumber daya manusia yang sehat dan berkualitas baik secara fisik, mental, dan sosial serta mempunyai produktivitas yang optimal. Untuk itu diperlukan upayaupaya pemeliharaan dan peningkatan kesehatan secara terus menerus dimulai dari sejak dalam kandungan, usia balita, usia sekolah, sampai usia lanjut. muda. Pendidikan kesehatan dibutuhkan dalam tahapan pembentukan perilaku hidup bersih dan sehat. Tahap perkembangan otak pada anak usia dini menempati posisi yang paling pesat yakni mencapai $80 \%$ perkembangan otak. Oleh karena itu, pemberian pendidikan kesehatan pada anak usia dini sangat baik dilakukan, dimana anak usia dini memiliki kemampuan memori yang kuat sehingga pendidikan kesehatan yang diberikan saat usia dini akan berpeluang besar menjadi suatu kebiasaan sehat di tahapan kehidupan selanjutnya. Kebiasaan kesehatan, dapat dilakukan melalui program pendidikan kesehatan, gizi, dan olah raga pada anak usia dini (Krauss A.F. and Barnett W.S., 2013).

Implementasi Undang-Undang tersebut telah dilaksanakan pemerintah melalui upaya pemeliharaan dan peningkatan kesehatan yang dilakukan melalui penerapan promosi kesehatan di sekolah sejak WHO (Word Health Organization) menerapkan konsep Health Promoting School, atau sekolah yang berwawasan kesehatan, atau sering juga diterjemahkan sebagai sekolah yang mempromosikan kesehatan. Sekolah diharapkan dapat menerapkan perilaku hidup sehat tersebut sebagai salah satu sarana peningkatan pengetahuan dan kemampuan warga sekolah dalam berperilaku hidup sehat. Dalam hal ini sekolah memiliki peran dalam menyumbang perubahan perilaku tersebut. Anak usia sekolah baik tingkat Pra Sekolah, Sekolah Dasar, dan Sekolah Menengah Pertama merupakan suatu masa usia anak yang sangat berbeda dengan usia dewasa. Pada periode usia ini, didapatkan banyak permasalahan kesehatan yang sangat menentukan kualitas anak dikemudian hari. Masalah kesehatan tersebut meliputi kesehatan umum, gangguan perkembangan, 
gangguan perilaku dan gangguan belajar. Permasalahan kesehatan tersebut pada umumnya akan menghambat pencapaian prestasi pada peserta didik disekolah. Sehingga, anak sekolah sebagai aset atau modal utama pembangunan dimasa depan sangat perlu dijaga, ditingkatkan dan dilindungi kesehatannya (Dermawan, 2012).

(Nation, 2010) menegaskan kembali bahwa sifat prediktif variabel kesehatan dan pendidikan dengan menyatakan bahwa pendidikan, kesehatan, gizi dan sanitasi saling melengkapi satu sama lain berkontribusi pada hasil yang lebih baik di negara lain dalam rangka pengembangan Human Development Index (HDI). Peneliti lain setuju dan pendidikan merupakan prediktor kunci peluang hidup, termasuk pembangunan ekonomi, kesejahteraan psikologis, status kesehatan dan lingkungan sosial (Buchmann C, 2010). Diakui bahwa siswa yang sehat lebih mampu dan siap untuk belajar, dan bahwa meningkatkan kesehatan siswa dan lingkungan sekolah memiliki hasil yang positif untuk pembelajaran dan hasil akademik.

Hasil dari wawancara yang telah dilakukan di Sekolah Dasar Negeri 29 Pekanbaru, diperoleh informasi dari salah satu guru bernama Bu Siti Nurhayati, S.Pd, mengatakan bahwa Sekolah Dasar Negeri 29 Pekanbaru sudah menumbuhkan perilaku hidup sehat sejak awal berdirinya sekolah, mulai dari kegiatan piket kelas yang dilakukan siswa guna kebersihan kelas, membuang sampah ke tempat sampah yang terpilah (sampah organik dan non organik), melakukan senam setiap sabtu pagi, dan cuci tangan dengan sabun sebelum masuk kelas. Namun, peneliti juga melihat masih ada perilaku yang belum menumbuhkan hidup sehat, seperti pada saat jam istirahat siswa masih ada yang jajan didepan pagar sekolah yang belum terjamin akan kebersihannya, seharusnya sekolah sesekali memberikan pengenalan jajanan sehat yang dapat mencegah keracunan jajanan anak sehingga jajanan yang dikonsumsi bergizi, sehat, dan higienis serta perilaku-perilaku hidup sehat lainnya. Hal Ini tentunya harus menjadi perhatian khusus bagi sekolah, karena jika siswa terus-menerus dibiarkan melakukan hal-hal yang tidak sesuai akan menimbulkan dampak yang tidak baik bagi kesehatan siswa. Hal ini tentunya harus ada kerjsama antara pihak sekolah dengan dinas kesehatan terkait menurut hasil penelitian (Sholikhah H.H. dan Sustini F., 2013) menyatakan peningkatan kerja sama yang lebih terprogram antara pihak sekolah dan petugas kesehatan setempat dalam memperketat aturan pengelolaan penjual jajan di sekitar sekolah, serta melakukan edukasi yang berkesinambungan baik di lingkungan sekolah maupun lingkungan komunitas tempat tinggal anak sekolah.

\section{METODE PENELITIAN}

Penelitian ini menggunakan kualitatif deskriptif. Adapun jenis penelitian ini adalah deskriptif, karena memenuhi maksud dan tujuan penelitian. Penelitian ini menjelaskan mengetahui dan mendeskripsikan peran kepala sekolah dan guru dalam menumbuhkan perilaku hidup sehat pada siswa Sekolah Dasar Negeri 29 Pekanbaru dengan kurun waktu penelitian dari bulan September 2020-April 2021. Dalam penelitian ini yang harus dilalui oleh peneliti yaitu dimulai dengan 1) wawancara bersama kepala sekolah, guru, dan siswa mengenai peran sekolah dalam menumbuhkan perilaku hidup sehat pada siswa di Sekolah Dasar Negeri 29 Pekanbaru. Obsevasi diarahkan kepada memperhatikan secara akurat, mencatat fenomena yang muncul, dan mempertimbangkan hubungan antara aspek dan fenomena yang terjadi. 2) merumuskan masalah. Setelah peneliti melakukan obervasi awal, peneliti merumuskan masalah yang tepat sesuai dengan judul yang telah peneliti ambil dan berdasarkan observasi awal yang peneliti lakukan. 3) pelaksanaan penelitian. Peneliti ke lapangan langsung untuk mencari data sehingga data tersebut dapat menjawab permasalahan yang peneliti angkat. Peneliti menggunakan teknik pengumpulan data observasi, wawancara dan dokumentasi. Penelitian ini digunakan teknik triangulasi sumber yang dicapai melalui cara membandingkan data hasil pengamatan dengan data hasil wawancara, observasi, dan dokumentasi. 
DOI: https://doi.org/10.31004/basicedu.v5i4.1196

\section{HASIL PENELITIAN DAN PEMBAHASAN.}

Berdasarkan berdasarkan hasil penelitian dapat dilihat bahwa kepala sekolah telah melakukan perannya dengan menggunakan 3 pendekatan yakni pendekatan pimpinan dengan menjadikan perannya sebagai pemimpin di sekolah untuk mewujudkan PHBS di sekolah, bina suasana dengan cara menciptakan suasana sekolah yang kondusif untuk melaksanakan PHBS dengan tidak hanya membuat lingkungan yang nyaman saja akan tetapi dengan menciptakan perilaku warga sekolah yang selalu ber-PHBS. Salah satunya yaitu dengan melakukan program sekolah sehat yaitu, JUMANTIK, menyetor sampah ke pihak bank sampah, dokter cilik, dan kantin sehat ber-BPOM. Hal ini tentunya diharapkan dapat membentuk perilaku hidup sehat dengan cara memberikan pengetahuan, kemudian di ikuti dengan penerapannya dengan harapan masyarakat di sekolah dapat termotivasi dalam menerapkan perilaku hidup sehat. Hasil penelitian yang dilakukan di Kota Manado menunjukkan, tindakan yang dilandasi oleh unsur pengetahuan akan lebih awet atau kekal dibandingkan dengan tindakan yang tidak dilandasi oleh pengetahuan (Saibaka, 2016).

Kemudian menurut Kemenkes RI (Yugo Sinatryo, 2017) dalam penelitiannya dijelaskan bahwa dalam menerapkan PHBS di sekolah ada langkah-langkah yang dilakukan secara bertahap antara lain: 1) menanamkan nilai-nilai untuk ber-PHBS kepada siswa sesuai kurikulum yang berlaku; 2) menanamkan nilainilai untuk ber-PHBS kepada siswa yang dilakukan diluar jam pelajaran biasa; 3) bimbingan hidup bersih dan sehat melalui konseling; dan 4) kegiatan penyuluhan dan latihan keterampilan dengan melibatkan peran aktif siswa, guru dan orang tua antara lain melalui penyuluhan kelompok, pemutaran kaset radio/fil, penempatan media poster, pemyebaran leaflet dna membuat majalah dinding.

Selain peran kepala sekolah, peran guru juga sangat penting dalam membentuk perilaku hidup sehat siswa. Adapun peran guru diantaranya membimbing pembiasaan perilaku hidup sehat terhadap siswa dengan membiasakan siswa berbaris di halaman sekolah saat pagi hari sebelum masuk kelas, mencuci tangan sebelum masuk kelas dan sebelum makan, serta membersihkan kelas dan halaman sekolah. Kemudian kegiatan perilakuhidup sehat salah satunya siswa diminta untuk melakukan cuci tangan setiap hari agar menjadi kebiasaannya. Pembiasaan mencuci tangan tersebut dicontohkan oleh guru diawali dengan menjelaskan pentingnya menjaga kebersihan agar tidak mudah sakit. Sejalan dengan pendapat (Mathur P., 2011) cuci tangan dengan sabun dan air mengalir dianjurkan saat tangan terlihat kotor, menggunakan toilet, dan sebelum dan sesudah makan. Kemudian pada setiap sabtu pagi wajib mengadakan senam, dengan durasi dari jam 07.30 - 08.00. Kegiatan lainnya yaitu gotong royong, minimal dua minggu sekali. Gotong royong di sekolah. kemudian mengajak siswa agar selalu menjaga kebersihan lingkungan dengan memilah sampah organik, nonorganik, dan sampah berbahaya yaitu kaca.

Selain itu siswa selalu diberikan pemahaman pentingnya hidup sehat agar terhindar dari penyakit, dengan menjaga kebersihan makanan, makan makanan yang bergizi, dan membersihkan makanan yang berserakan dibuang ditempat sampah yang sudah disediakan di sekolah. Tentunya dengan lingkungan yang bersih dan sehat akan membuat warga di sekolah akan menjadi lebih membiasakan berperilaku lebih sehat. Menurut (Lolowang, 2017) kepedulian anak sangat diperlukan terkait dengan perilaku hidup bersih dan sehat. perilaku hidup bersih dan sehat harus menjadi cerminan untuk semua orang dimulai dari masa kanak-kanak. Selain itu, berdasarkan hasil penelitian (Daniah, 2019) pelatihan siswa dasar dalam pembuangan dan pemilahan sampah rumah tangga dari segi pengetahuan siswa SD masih banyak yang tidak mengatahui dalam pemilihan sampah dan seberapa pentingnya manfaat jika dilakukan pemilihan sampah, sehingga setelah dilakukan intervensi pemahaman atau pengetahuan dalam memilah sampah rumah tangga jadi mengatahui dan lebih baik. Sedangkan sikap yang selama ini mereka tidak peduli dengan sampah, tidak mau tahu sampah rumah tangga itu sebaiknya di pilah pilah atau tidak, setelah dilakukan intervensi atau pelatihan, sikap siswa SD sangat responsive terhadap pemilahan sampah, terbukti dalam oservasi 1 minggu dengan pengawasan kader, siswa SD sudah mengetahui jenis-jenis sampah organik dan sampah non organik. Berdasarkan dari 
penelitian yang telah dilakukan sebelumnya, bahwa pentingnya kesadaran siswa dalam membentuk perilaku sehat sangat dipengaruhi oleh lingkungan sekitar terutama oleh guru dan orang tua.

Hasil penelitian ini sejalan dengan penelitian yang dilakukan oleh (Ningsih, 2014) mengatakan bahwa kondisi kesehatan lingkungan sekolah yang baik atau pun buruk dapat mempengaruhi perilaku hidup bersih dan sehat (PHBS) pada semua siswa. (Perdana, 2016) mengatakan bahwa SD Al-Irsyad memiliki kesehatan lingkungan sekolah yang baik karena mereka mendapat perhatian yang lebih besar sehingga lebih mudah menerapkan kebiasaan-kebiasaan yang baik terhadap perilaku hidup bersih dan sehat. Selain itu perilaku hidup bersih dan sehat merupakan salah satu faktor penting dalam pendidikan anak sekolah dasar untuk pembentukan perilaku kesehatan sejak dini di institusi pendidikan dan untuk memberdayakan siswa, guru dan masyarakat lingkungan sekolah agar tahu, mau dan mampu mempraktikkan perilaku hidup bersih dan sehat dan berperan aktif dalam mewujudkan sekolah sehat (RenitaTrisna, 2017).

Selain itu berdasarkan hasil observasi terkait dalam memfasilitasi pengembangan kebijakan yang mendukung pelaksanaan perilaku hidup sehat di sekolah sudah terdapat adanya tempat cuci tangan yang bersih, UKS, serta obat ABATE yang diberikan oleh pihak PUSKESMAS untuk mengendalikan larva nyamuk. Guru menyatakan bahwa fasilitas yang mendukung penumbuhan perilaku hidup sehat di sekolah, yaitu adanya air mengalir yang bersih, dan sabun. Lalu fasilitas yang mendukung penumbuhan perilaku hidup sehat di sekolah, yaitu salah satunya disediakan tempat cuci tangan dan pada saat pandemi sekarang ini, siswa diberikan masker. Penelitian (Fatmawati, 2019) yang menyatakan bahwa beberapa masalah kesehatan yang di alami siswa sekolah dasar yaitu berhubungan dengan kebersihan diri/personal hygiens anak dan lingkungan, seperti halnya menggosok gigi yang sesuai, kebiasaan cuci tangan menggunakan sabun dan air mengalir, serta kebersihan diri. Beliau menyarankan terhadap pihak sekolah khususnya guru dan petugas UKS untuk dapat mendorong siswa dan meningkatkan pengetahuan serta pemahamannya terhadap pentingnya kebersihan diri. Jika ada siswa yang tidak mengikuti aturan yang ada di sekolah maka siswa akan diberikan peringatan secara lisan dan bagi yang berperilaku hidup sehat maka akan diberi pujian agar mereka lebih termotivasi dalam melaksanakan perilaku hidup sehat. Hal ini sejalan dengan penelitian yang dilakukan oleh (Satria Irwandi, Nurul Ufatin, 2016) penghargaan kepada siswa seperti pujian dan perhatian diberikan kepada siswa yang berperilaku hidup sehat di sekolah, sedangkan sanksi berupa peringatan secara lisan diberikan kepada siswa yang melanggar.

\section{KESIMPULAN}

Berdasarkan hasil penelitian di atas yang telah peneliti lakukan melalui tiga teknik pengumpulan data, baik wawancara, observasi dan dokumentasi, maka peran kepala sekolah dan guru dalam menumbuhkan perilaku hidup sehat sudah cukup baik. Peran kepala sekolah berdasarkan penelitian yaitu mempengaruhi siswa, bertindak, mengawasi dan menggerakkan siswa dalam penumbuhan perilaku hidup sehat yang sudah dijalankan. Dalam hasil penelitian sekolah berupaya menjalankan program sekolah sehat. Selain itu ada beberapa faktor yang mempengaruhi penerapan budaya sekolah dalam mewujudkan sekolah sehat yaitu Faktor pendukung terdiri sumber daya manusia yang aktif dan sarana prasarana untuk memenuhi standar sekolah sehat, bekerjasama dengan pihak luar baik orangtua siswa, Dinas Pertanian, Dinas Lingkungan Hidup, dan Dinas Kesehatan, BPOM (Badan Pengwasan Obat \&Makanan), Dinas Kesehatan Kota, dll. Sedangkan faktor penghambat terdiri dari kurangnya pembiasaan dalam menerapkan perilaku hidup bersih dan sehat, masih banyaknya pedagang jajanan yang berjualan diarea sekolah yang juga belum dapat dipastikan jajan tersebut sehat atau tidak 

Dasar - Nurul Anisa, Zaka Hadikusuma Ramadhan

DOI: https://doi.org/10.31004/basicedu.v5i4.1196

\section{DAFTAR PUSTAKA}

Buchmann C, D. T. \& M. A. (2010). Gender Inequalities In Education. Annual Review Of Sociology. 34(1), 319-337.

Cvencek, D, Dkk. (2017). Self-Concepts, Self-Esteem, And Academic Achievement Of Minority And Majority North American Elementary School Childre.N. Child Development. 89(4), 1099-1109.

Daniah. (2019). Peran Siswa Sekolah Dasar Dalam Perubahan Perilaku Pembuangan Sampah Organik Dan Pemanfaatan Pembuangan Akhir. Ilmiah Ilmu Keperawatan Indonesia, 9(4), 681-684.

Dermawan, D. (2012). Buku Ajar Keperawatan Komunitas Edisi 1.

Fatmawati, T. Y. (2019). Meningkatkan Personal Hygiena Pada Siswa SD Negeri Kecamatan Kota Baru. Jurnal Abdimas Kesehatan (JAK), 1(1), 12.

Indah Prasetyawati Tri Purnama Sari. (2013). Pendidikan Kesehatan Sekolah Sebagai Proses Perubahan Perilaku Siswa. Jurnal Pendidikan Jasmani Indonesia., 9(2).

Irwandi, S., Ufatin, N., \& S. (2016). Peran Sekolah Dalam Menumbuhkembangkan Perilaku Hidup Sehat Pada Siswa Sekolah Dasar (Studi Multi Situs Di SD Negeri 6 Mataram Dan SD Negeri 41 Mataram Kota Mataram Nusa Tenggara Barat). Jurnal Pendidikan, 1(3), 492-498.

Kandou, G. D., \& Caroline, P. (2019). Improving Students Knowledge Of Clean And Healthy Living Behavior Through Health Education. 412-416. Proceedings Of The 3rd Asian Education Symposium (AES 2018), 253(Aes 2018), 412-416.

Krauss A.F. And Barnett W.S. (2013). Early Childhood Education: Pathways To Better Health. Policy Brief. NIEER. National Institute For Early Education Research.

Lolowang, Dkk. (2017). Gambaran Perilaku Hidup Bersih Dan Sehat Di Sekolah Dasar Inpres Talikuran Kecamatan Kawangkoan Utara. " Media Kesehatan, 9(3).

Mathur P. (2011). Hand Hygiene: Back To The Basics Of Infection Control. Indian J 134(5): 611-620. Indian J Med Res.;, 134(5), 611-620.

Minsih, M., \& D, A. (2018). Peran Guru Dalam Pengelolaan Kelas. Profesi Pendidikan Dasar, 1(1), 20.

Nation, U. (2010). Human Development Report. The Real Wealth Of Nations: Pathways Of Human Development. New York: United Nations Development Programme.

Ningsih, D. Y. (2014). Hubungan Kondisi Lingkungan Sekolah Dengan Perilaku Hidup Bersih Dan Sehat (Phbs) Pada Siswa SMA Negeri Di Kota Sanggau Tahun 2014. Jurnal Mahasiswa PSPD FK Universitas Tanjungpura, 1(1).

Perdana, F. S. Y. (2016). Peran Lingkungan Keluarga Dan Sekolah Terhadap Perilaku Hidup Bersih Dan Sehat (Phbs) Siswa Sekolah Dasar Negeri 06 Petarukan Dengan Sekolah Dasar Al-Irsyad Dikabupaten Pemalang.

Saibaka. (2016). Hubungan Antara Pengetahuan Dan Sikap Dengan Perilaku Hidup Bersih Dan Sehat Rumah Tangga Di Wilayah Kerja Puskesmas Wawonasa Kota Manado'. Jurnal Kesehatan, 7-11.

Satria Irwandi, Nurul Ufatin, S. S. (2016). Peran Sekolah Dalam Menumbuhkembangkan Perilaku Hidup Sehat Pada Siswa Sekolah Dasar (Studi Multi Situs Di Sd Negeri 6 Mataram Dan Sd Negeri 41 Mataram Kota Mataram Nusa Tenggara Barat). Jurnal Pendidikan: Teori, Penelitian, \& Pengembangan, 1(3).

Sholikhah H.H. Dan Sustini F. (2013). 2013. Gambaran Perilaku Hidup Bersih Dan Sehat Tentang Food Borne Disease Pada Anak Usia Sekolah Di SDN Babat Jerawati Kecamatan Pakal Kota Surabaya. Buletin Penelitian Sistem Kesehatan, 16(4), 351-362.

Yufiarti, Y., Edwita, \& S. (2019). Health Promotion Program (JUMSIH); To Enhance Children's Clean And Healthy Living Knowledge. JPUD-Jurnal Pendidikan Usia Dini, 13(2), 341-355. 
2269 Peran Kepala Sekolah dan Guru dalam Menumbuhkan Perilaku Hidup Sehat pada Siswa Sekolah Dasar - Nurul Anisa, Zaka Hadikusuma Ramadhan

DOI: https://doi.org/10.31004/basicedu.v5i4.1196

Yugo Sinatryo. (2017). Usaha Dan Peran Kepala Sekolah Dalam Mewujudkan PHBS Di SD Hang Tuah Sidoarjo. Jurnal Inspirasi Manajemen Pendidikan, 5(1). 